\title{
PERSEPSI DAN HARAPAN PEMUSTAKA TERHADAP PENGEMBANGANSISTEM MANAJEMEN PERPUSTAKAAN UIN RADEN INTAN DI ERA COVID 19 MENUJU NEW NORMAL LIFESTYLE
}

\author{
Rodiyah*), Rohai Inah Indrakasih**) \\ Universitas Islam Negeri Raden Intan Lampung, Indonesia \\ e-mail: rodiahsarianwar@gmail.com*) dan inahindrakasih@gmail.com**) \\ Naskah diterima: 30 April; direvisi: 21 Mei; disetujui: 2 Juni 2020
}

\begin{abstract}
Abstrak
Abstract

The development of information and communication technology is very fast affecting various fields of life and professions. The changes that were accompanied by the potential offer of telematics also caused a paradigm shift in the field of higher education. The paradigm changes include E-Learning, E-Research, and information literacy which requires libraries to develop to support the smooth running of education, research and society. This reserach uses participatory observation method. The subjects of this study were active library users of UIN Raden Intan Lampung. Data collection in this research is through questionnaire surveys, interviews, and document studies. The results of the study are the perceptions and expectations of users to the development of Raden Intan Library in the digital era is the merging of the Four building concepts: the concept of green library, Academic Library, Supermarket Library and Home Library.
\end{abstract}

Keywords: Digital Library, Perception and Expectations, visitors of library, Library Management. 


\section{PENDAHULUAN.}

Pandemi Covid-19 (coronoavirus disease) 2019 pertama kali dideteksi di kota Wuhan, Provinsi Hubei, Tiongkok pada bulan Desember 2019. Dan masuk ke Indonesia pertama kalinya pada awal maret dengan diumumkannya dua kasus pasien positif Covid-19 oleh pemerintah Indonesia. Namun, menurut Pakar Epidemiologi Universitas Indonesia (UI) menyebutkan virus corona jenis SARS-Cov-2 sebagai penyebab Covid-19 sudah masuk ke Indonesia sejak awal Januari (compas.com).

Sejak bulan maret 2020, masyarakat Indonesia terpapar Covid 19 semakin meningkat, oleh karena itu, pada tanggal 16 Maret 2020, Presiden Indonesia (Kompas.com) untuk menekan perkembangan wabah covid 19 ini, menginstruksikan seluruh pegawai baik negeri maupun swasta untuk bekerja dari rumah (Work From Home).

Perintah Work From Home (WFH) ini, juga dilaksanakan di UIN Raden Intan Lampung, termasuk perpustakaan baik di pusat maupun di fakultas. Tentu saja perintah WFH ini cukup mengagetkan dan membingungkan civitas akademika terutama pegawai yang berkerja di perpustakaan di bagian pelayanan dan pengolahan bahan pustaka. Dampak ini tidak saja terjadi pada pegawai perpustakaan saja tetapi juga pengguna perpustakaan yaitu pemustaka. Karena, meskipun mahasiswa diliburkan, mereka tetap kuliah daring, tetap mengerjakan tugas dari dosen, tetap perlu bahan bacaan untuk menambah wawasan. Begitu juga mahasiswa yang sedang melaksanakan penelitian untuk tugas akhir mereka, sangat membutuhkan informasi untuk menyelesaikan tugas akhir mereka.

Untuk memenuhi kebutuhan informasi, pemustaka melakukan kunjungan perpustakaan dengan datang langsung keperpustakaan dan mencari dokumen lalu meminjamnya. Tetapi kegiatan ini tidak bisa terlaksana karena selama WFH perpustakaan tutup.

Perpustakaan UIN Raden Intan berdasarkan Peraturan Menteri Agama RI nomor 22 tahun 2017 berbentuk UPT Perguruan Tinggi. Perpustakaan UIN Raden Intan termasuk perpustakaan hibryda yaitu antara konvensional dan digital yang membutuhkan pengembangan disegala bidang baik layanan maupun koleksi perpustakaan, terutama sistem manajemen perpustakaan dari Visi, Misi, sasaran, tujuan, kegiatan dan program yang ditawarkan ke pengguna perpustakaan (pemustaka).

Pada Era Covid 19 menuju new normal lifestyle, menuntut pegawai perpustakaan untuk bekerja dirumah namun layanan perpustakaan tetap berjalan seperti biasa, tentu menimbulkan berbagai tanggapan berupa persepsi dan harapan dari berbagai kalangan, terutama dari para pemustaka (masyarakat akademik yaitu mahasiswa, peneliti, dosen, dan karyawan). Para pemustaka ini merupakan pelanggan perpustakaan yang mencari informasi dan pengetahuan dalam rangka memenuhi kebutuhan mereka di dunia akademik yaitu belajar dan mengejar, penelitian dan pengabdian kepada masyarakat. Tentu saja mereka berharap selama mereka dirumah (belajar, mengajar, meneliti dan bekerja), mereka tidak mengalami kesulitan dalam memperoleh informasi yang dibutuhkan demi kelacaran kegiatan mereka dalam pengelolaan informasi dan pengetahuan dengan memanfaatkan teknologi informasi dan komunikasi yang ada di perpustakaan. Jenis layanan (jasa) perpustakaan yang berbasis teknologi informasidisajikan ke pemustaka tentu saja akan lebih praktis, ekonomis, cepat dan tepat guna selama mereka belajar di rumah.

Dengan ad anya penelitian ini,Perpustakaan sebagai pusat informasi dan layanan litarasi dapat mengetahui persepsi dan harapan pemustaka terhadap pengembangan sistem manajemen perpustakaan, dengan tujuan agar koleksi dan layanan yang disajikan oleh perpustakaan sesuai atau mendekati kebutuhan pemustaka terhadap informasi dengan cepat dan tepat pada era Covid 19 menuju New Normal Lifestyle

\section{METODE PENELITIAN}

Penelitian ini menggunakan metode observasi partisipatoris yaitu penulis ikut terlibat dalam sistem manajemen perpustakaan selama penelitian dan memperhatikan gejala-gejala perilaku pemustaka yang tampak di perpustakaan UIN Raden Intan Lampung. Subjek dari penelitian ini adalah pemustaka UIN Raden Intan Lampung yang menjadi anggota aktif perpustakaan pusat angkatan 2016, 2017, dan 2018. pengumpulan data dalam penelitian ini yaitu melalui survei kuesioner, wawancara, dan studi dokumen.

Analisis data dilakukan dengan cara melakukan persentase jawaban-jawaban responden dari setiap pernyataan yang ada di dalam kuesioner. Hasil persentase tersebut 
disajikan dalam bentuk tabel frekuensi dan selanjutnya diinterprestasikan dalam bentuk kalimat agar dapat dipahami maksudnya.

\section{LANDASAN TEORI}

\section{A. Konsep Pengembangan Sistem Manajemen Perpustakaan}

S i s te m M a n a j e m e n ( K a m u s Kepustakawanan Indonesia, 2009, hlm. 316) adalah sistem yang berbasis komputer untuk mendefinisikan, membuat, memanipulasi, mengawasi, mengatur, dan menggunakan basis data. System ini memungkinkan adanya penyimpanan, pengolahan, akses, keamanan, dan mengintegrasikan menjadi bahan pendukung keputusan/decision support system.

Metode atau sistem dalam kajian perpustakaan (Sutarno, 2006, hlm. 141) mencakup: akuisis, pengolahan, dan layanan yang berbasis komputer.

1. Akusisi, yaitu dimulai dari proses pengadaan koleksi perpustakaan baik buku, jurnal, maupun bahan video dan audio, kegiatan ini dimulai dari pembuatan perencanaan pengadaan koleksi, proses seleksi berdasarkan prioritas kebutuhan sesuai data permintaan, dan penyusunan RAB (Rencana Anggaran Belanja) untuk pembelian.

2. Pengolahan, yaitu dimulai pendataan dokumen dengan memanfaatkan Tekonlogi informasi dan komunikasi, untuk pendataan dokumen pustakwan menggunakan panduan buku pedoman dan peraturan-peraturan seperti dalam klasifikasi, katalogisasi, dan penentuan tajuk subyek dan lainnya

3. Layanan/jasa, misalnya layanan sirkulasi yaitu peminjaman dan pengembalian; layanan umum seperti, keanggotaan, fotocopy, pengiriman dokumen; layanan literasi informasi seperti bimbingan pemakai dan sebagainya

Dengan demikian bahwa sistem manajemen perpustakaan adalah sistem berbasis komputer dalam proses manajemen perpustakaan dari akusisi, pengelolaan hingga layanan perpustakaan. Perubahan Mind site pada System Manajemen perpustakaan sudah diprediksi oleh Stueart and Morgan (Hartono, 2016, hlm. 4) ini dapat dilihat pada bagan dibawah

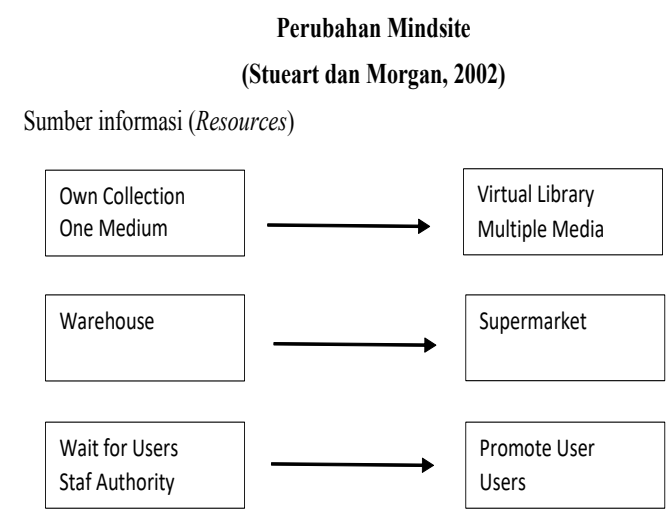

Pada gambar di atas, Perpustakaan mengalami perubahan yaitu pertama, pada koleksi terjadi perubahan dari one media ke multiple media, yaitu ada perkembangan dalam koleksi perpustakaan dari bentuk buku, majalah dan jurnal berkembang menuju e-book, e-journal, e-magazine, e-newspaper, dan termasuk pangkalan data dalam media elektronik. Begitu juga fisik perpustakaan mengalami perubahan dari perpustakaan konvensional yang telah menerapkan manajemen berbasis komputer, memungkinkan terbentuknya perpustakaan virtual.

Kedua, terjadi perubahan pada Layanan/ jasa perpustakaan yaitu dulu pemustaka ketika ingin meminjam koleksi perpustakaan mereka wajib datang langsung dan memilih buku yang dibutuhkan tetapi sekarang terjadi perkembangan bahwa layanan perpustakaan sudah menyerupai layanan supermarket, yaitu adanya layanan daring, pengiriman (delivery), diskon denda, hadiah hadiah untuk pemustaka yang rajin baca dan rajin berkunjung ke perpustakaan baik datang langsung ke perpustakaan maupun hadir di perpustakaan virtual, ada perlombaan perlombaan, ada seminar, ada acara pertemuan antara penulis dan pembaca baik real maupun melalui website seminar (webinar) dan sebagainya.

Ketiga, seorang pustakawan bukan sebagai penjaga buku yang menunggu pemustaka datang untuk membaca lalu melayani, namun pustakawan dituntut kreatif, inovatif dan informatif. Pustakawan dituntut banyak melakukan promosi perpustakaan, menciptakan inovasi inovasi baru bagi layanan perpustakaan dan selalu informatif terhadap kebutuhan pemustakaan dan perilaku pemustaka dalam mencari informasi. 


\section{B. Konsep Pengembangan Perpustakaan Sesuai Dengan Tujuan Akademik/ Perguruan Tinggi}

Tujuan dibangun perpustakaan digital (Pendit, Laxman Puru, 2017, hlm. 29) yaitu mendukung: Pertama, Mendukung paradigma $e$ learning. Dimana e-learning memungkinkan a) adanya pemanfaatan teknologi jaringan untuk pemakaian informasi secara bersama antara pengajar dan mahasiswa dari berbagai tempat terpisah, sekaligus melakukan pembaruan (updating), penyimpanan, penemuan, dan penyebaran pengetahuan secara terus menerus; b) penggunaan media digital secara bersamasama seperti zoom, meet dan sebagainya; c) mendukung pembelajaran jarak-jauh (distance Learnin)

Kedua, Mendukung paradigma e-research, untuk memanfaatkan sumberdaya pengetahuan bersama-sama dalam rangka mendukung kegiatan penelitian kolaboratif dan multidisipliner. Ketiga, mendukung Information Literacy dengan memanfaatkan website seminar (webinar), sehingga keterampilan yang tidak hanya menyangkut kemampuan membaca atau memahami informasi digital, tetapi juga keterampilan mencari, menemukan, dan memilih informasi di antara timbunan big data digital dapat dilakukan di dunia maya.

Di Era Covid 19 hingga New Normal, perpustakaan dituntut mampu menjadi partner, pendamping bagi dosen, peneliti, penceramah, mahasiswa dan staf kependidikan dalam menjalankan tugasnya masing masing oleh karena itu layanan dan koleksi perpustakaan harus sejalan dengan kegiatan e-learning, $e$ research dan Information Literacy sehingga tujuan yang diharapkan dari tingkat manajemen bawah hingga top manajemen dapat tercapai.

\section{Konsep Pengembangan Perpustakaan Berbasis Pengguna}

Pada era digital telah terjadi transformasi dalam masyarakat, Febrice Papy menyatakan, (Febrice Papy, 2008, hlm. 3) "readers no longer concentrate on one single type of activity. At their wokstation they easily move form evaluation tasks to social acitivities. Work and socil activities are higly interlinked. Technologicl innovtions open up these possibilites and the user' behavior is adapting to them". Terjadi perubahan prilaku pembaca, mereka tidak hanya konsentrasi pada satu jenis aktivitas saja melainkan beragam aktivitas. Bagi pemustaka, membaca itu bukan lagi sekadar untuk membaca, melainkan hasil bacaan tersebut dapat dimanfaatkan dalam berbagai aktivitas. Teks sebagai susunan kata kata yang teratur dapat digunakan menjadi sumberdaya yang dapat berpindah pindah makna, dapat di copy and paste, dan dapat untuk dikutip atau dirujuk yaitu dari bentuk tugas evaluasi ke aktivitas sosial. Aktivitas kerja dan sosail sangat saling terkait. Oleh karena itu sistem teknologi informasi perpustakaan dikembangkan sesuai dengan prilaku dan kebutuhan pemustaka pencari informasi.

Melihat terjadi perubahan kebiasaan membaca diatas, Dian Wulandari (Hartono, 2017, hlm. 30) menyampaikan bahwa perpustakan perlu dibangun sesuai norma net generatiaon yang memiliki fitur-fitur : one stop searching, Single Sign On, Accessibility, Search Engine, User Friendly dan memiliki efek-efek visual yang menarik pada web situs.

Dengan demikian, setiap pemustaka perpustakaan perguruan tinggi diberi satu akun dan satu password untuk masuk situs web perpustakaan (Single Sign On). Akun dan password ini juga dapat digunakan untuk melihat perkembangan mutu pendidikan mereka pada program SIAKAD. Selain itu Search Engine sebaiknya bersifat aksesibilitas (memiliki kemudahan penggunaan) dan user friendly sehingga pemustaka tidak bingung ketika memanfaatkan layanan perpustakaan online. Agar pemustaka tidak jenuh dan bosan sebaiknya situs web dan sistem informasi perpustakaan bersifat interaktif yaitu memungkinkan para pengguna perpustakaan saling berinteraksi dengan pengguna lainnya, melakukan information sharing, memberikan review terhadap koleksi perpustakaan, melakukan pemesanan koleksi, pengusulan koleksi, bertanyajawab dengan pustakawan melalui fasilitas email maupun chatting, dan lain sebagainya; serta Memiliki efek-efek visual yang menarik seperti: tampilan visual cover buku, Simbol-simbol penunjukan lokasi koleksi secara visual dan lain sebagainya.

Dari uraian diatas dapat disimpulkan bahwa pemustaka di era digital terutama pada era New Normal lifestye ini, perpustakan perlu dikembangkan sesuai prilaku membaca yakni Pertama, kebebasan dalam mengeksplorasi koleksi-koleksi perpustakaan secara mandiri; dapat berkomunikasi secara interaktif baik itu dengan pengajar, peneliti maupun pemustaka; dan dapat mempublikasikan karyanya secara langsung. Kedua, Teknologi informasi dan 
komunikasi yang ditawarkan kepada pemustaka memiliki kemudahan kemudahan (User Friendly) dalam penggunaannya terutama dalam hal pencarian informasi dari sumber-sumber yang dibutuhkan.

\section{Konsep Pengembangan Perpustakaan Berbasis Penglola Perpustakaan}

Pustakwan di era sekarang dituntut memiliki soft skill yang baik. Menurut Wiji Suwarno (Wiji Suwarno, 2016, hlm. 20) ada 4 soft skill yang wajib dimiliki seorang pustakawan yaitu Listening skills, Communications Skills, Public relations, dan kerjasama.

1. Listening skills, yaitu pustakawan diharapkan memiliki kemampuan mendengar semua keluhan baik itu berupa kritik, ide-ide, maupun saran dari pemustaka.Melalui keluhan atau ungkapan baik menyenangkan (berupa pujian, penghargaan ) maupun tidak menyenangkan (kritik pedas) dari pemustaka ini, kita dapat mengetahui kekurangan dan kelebihan perpustakaan kita terhadap (jasa) layanan terhadap pemustaka dan kekayaan koleksi kita miliki apakah sudah memenuhi kebutuhan informasi mereka

2. Communications Skills: ada dua Kemampuan berkomunikasi yang wajib dimiliki oleh seorang pustakawan yaitu tertulis dan tak tertulis. Tertulis dapat berupa pengumuman, poster, iklan, gambar dan sebagainya yang disampaikan bisa melalui proses pengiriman pesan dengan memanfaatkan teknologi komunikasi seperti WhatsApp, Facebook, Instagrams, atau Twitters. Sedangkan tak tertulis yaitu interaksi antara pustakawan dengan pemustaka dengan menggunkan bahasa verbal (lisan) maupun non-verbal (bahasa tubuh, isyarat) yang sopan dan santun.

3. Public relations: yaitu kemampuan membangun relasi dengan berbagai lembaga, organisasi, forum dan sebagainya seperti Ikatan Pustakawan Indonesia (IPI), Ikatan Guru Indonesia (IGI), IDI (Ikatan Dosen Indonesia), karena melalui lembaga dan forum ini, pustakawan dapat mengembangkan skill (keahlian) dan pengetahuan di berbagai bidang ilmu. Pustakawan yang memiliki kemampuan dibidang keahlian dan memiliki pengetahuan yang cukup luas dapat memenuhi kebutuhan informasi pemustaka, baik kebutuhan individu maupun kebutuhan kolektif.

4. Membangun kerjasama, perpustakaan yang melakukan kerjasama dengan lembaga lembaga sejenis dapat mengatasi masalahmasalah kekurangan di bidang koleksi yangdibutuhkan pemustaka dan masalah dana (pengadaan buku manual maupun buku elektronik) di perpustakaan yang kecil. Kerjasama ini dapat berupa peminjaman koleksi berupa buku antar perpustakaan.

\section{E. Konsep Pengembangan Perpustakaan berbasis Persepsi dan Harapan Pelanggan.}

Persepsi (Kinicki dan Robert, 2003, hlm. 67) dapat diartikan sebagai berikut Perception is a cognitive process that enables us to interpret and understand our surroundings. Persepsi adalah proses kognitif yang dialami oleh setiap orang dalam melakukan interpertasi dan memahami informasi tentang lingkungannya. Lebih lanjut Schermerhorn (Schermerhorn, 2005, hlm. 100) menjelaskan bahwa Perception is the process of receiving information about and making sense of our environment. This includes deciding which information to notice as well as how to categorize and interpret it. Persepsi adalah proses penerimaan informasi dan pemahaman tentang lingkungan yang melibatkan pancaindra (pengelihatan, pendengaran, penghayatan dan perasaan) termasuk penetapan informasi untuk membentuk pengkategorian dan penafsirannya.

Dari kedua pendapat ini dapat diambil kesimpulan bahwa persepsi merupakan proses kognitif dalam memahami informasi yang diterima, termasuk penetapan informasi untuk membentuk pengkategorian dan penafsiran. Dari pengategorian dan penafsiran ini maka terbentuklah penilaian atau kesan di dalam lapangan penginderaan seseorang. Dengan kata lain persepsi merupakan proses pencocokan informasi yang diterima dengan 'pola' yang sudah tersimpan dalam memori manusia

Sedangkan, Pengertian Harapan (Kamus Besar Bahasa Indonesia, KBBI Dering), adalah keinginan supaya menjadi kenyataan. Dengan demikian persepsi dan harapan seseorang adalah hasil anlisis informasi yang diterima dengan 'pola' sudah tersimpan dalam kognitif manusia mengenai lingkungannya, kemudian mengalami proses pengolahan dalam otak manusia lalu 
dikeluarkan dalam bentuk penyampaian secara tertulis atau tak tertulis dalam bentuk pengetahuan baru. Kemudian Pengetahuan baru ini dikomunikasikan agar menjadi kenyataan dan dilaksanakan.

Model pengembangan manajemen perpustakaan baru diharapkan merupakan hasil proses pemikiran para pemustaka (civitas akademik yakni mahasiswa, dosen, peneliti, staf kependidikan) yang dikembangkan menjadi kekinian sesuai kebutuhan pengguna perpustakaan atau sesuai dengan persepsi dan harapan pemustaka.

\section{HASIL DAN PEMBEHASAN}

\section{A. Persepsi Mengenai Sistem Perpustakaan UIN Raden Intan Sekarang (Existing)}

Layanan Perpustakaan Pusat tidak integrasi dengan perpustakaan fakultas terutama berkaitan dengan keanggotaan, bebas perpustakaan, wajib serah simpan karya ilmiah karena mahasiswa selain wajib menjadi anggota perpustakaan pusat mereka juga wajib menjadi anggota perpustakaan fakultas untuk memanfaatkan layanan dan sumber informasi di perpustakaan termasuk bebas perpustakaan baik di perpustakaan pusat maupun perpustakaan fakultas. Selain itu juga mengenai data koleksi di OPAC antara perpustakaan pusat dan perpustakaan fakultas tidak terintegrasi sehingga jika mahasiswa mencari suatu judul buku, mereka harus ke perpustakaan pusat atau perpustakaan fakultas untuk menemukan dokumen yang dicari. Namun menurut pemustaka bahwa koleksi perpustakaan pusat kurang relevan dan tidak mutakhir ini sesuai wawancara dengan responden 1 (15 Maret 2020).

"Buku yang saya cari di perpustakaan pusat sering tidak tersedia, lalu saya mencari perpustakaan fakultas, meskipun ada tetapi terbitan lama. Saya butuh tahun terbitan yang terbaru".

Hasil wawancara tersebut menunjukkan bahwa ada beberapa judul yang menjadi koleksi perpustakaan terbitan lama meskipun sudah ada terbitan baru. Oleh karena itu pemustaka menganggap koleksi perpustakaan pusat ada yang kurang relevan dan tidak mutakhir.

Tentu saja hasil wawancara dengan responden ini kami lanjutkan ke pimpinan perpustakaan, menurut kepala perpustakan pusat bahwa koleksi perpustakaan pusat pada umumnya bersifat hanya mengayaan saja. Untuk buku buku yang memiliki sabjek relevan dan sesuai dengan kurikulum, lebih banyak diletakan di perpustakaan fakultas, tujuannya untuk mendekatkan ke pengguna perpustakaan, sehingga pengguna perpustakaan akan merasa lebih nyaman tak perlu menuju ke perpustakaan pusat cukup di perpustakaan fakultas dalam memperoleh informasi sesuai kebutuhan akademik

Namun, pada era Covid 19, Sebagian besar mahasiswa menganggap Perpustakaan UIN Raden Intan sulit diakses sedangkan mahasiswa wajib belajar dirumah. Perpustakaan Pusat hanya memiliki layanan Repository berupa data buku yang dimiliki. Untuk meminjamnya mahasiswa wajib datang langsung ke perpustakaan lalu mencari buku tersebut dan melakukan transaksi peminjaman. Sehubungan dengan hasil penelitian ini, perpustakaan perlu kerjasama dengan pihak yang menyediakan layanan pengiriman barang ke pelanggan seperti gosend pada aplikasi gojek dan pembayaran melalui gopay sehingga pemustaka yang wajib belajar dirumah tidak perlu datang ke perpustakaan. Selain itu koleksi perpustakaan perlu diperbanyak dalam bentuk ebook yang memungkinkan pemustaka dapat melakukan pencarian, pemilihan dan men-download sendiri buku yang akan dibaca.

Untuk itu diperlukan Staf perpustakaan yang kreatif dan inovatif, selama ini pustakawan UIN Raden Intan kurang menginformasikan kepada pemustaka mengenai koleksi dan jasa/ layanan perpustakaan baru yang tersedia di perpustakaan. Staf wajib mendampingi pemustaka meskipun bekerja dari rumah (ketika lockdown) mereka harus mendengarkan dan memenuhi permintaan pemustaka. Pustakawan terus menerus menawarkan jasa layanan penelusuran ebook dan ejournal gratis bagi pemustakanya.

Adapun cara mengingatkan atau memberitahukan yang efektif (Sutarno, 2006, hlm. 101) yaitu melalui promosi dan publikasi dengan cara-cara yang dilakukan antara lain : 1 . Memajang bahan pustaka baru atau bidangbidang tertentu di ruang pamer yang sudah disediakan, namun di era covid 19 pustakawan dapat mengirimkan informasi dalam bentuk brosur brosur ke media sosmed seperti WhatsApp Group mengenai ebook atau e-journal atau bisa juga pustakawan mengirimkan link-link 
resources yang dapat di download gratis ke pemustak;a 2) menerbitkan dan menyebarkan daftar tambahan pustaka, dan dapat juga menawarkan layanan bahwa buku tersebut dapat dipinjam dan diantar melalui jasa kurir; 3) menyebarkan lembaran informasi terbaru atau terseleksi, 4) menerbitkan dan menyebarkan buletin perpustakaan. Menurut Webb (Webb, 1988, hlm. 16) bahwa ada 2 hal yang penting dalam memberi layanan, yaitu menjaga kontak dengan pemustaka dengan cara memberitahukan layanan apa saja yang dapat mereka manfaatkan di perpustakaan dan memberi informasi tentang layanan dan sistem yang ada serta menyediakan dengan tepat.

Ada beberapa peraturan perpustakan yang ditetapkan tidak sesuai dengan kebutuhan dan keinginan pemustaka seperti jam buka sesuai dengan jam kerja pegawai (08.00 wib - 16.00 wib), lama peminjaman hanya seminggu, jumlah buku yang boleh dipinjam hanya maksimal tiga buah buku, besarnya denda dan lain sebagainya.

OPAC/katalog dan Repository UIN Raden Intan Lampung cukup mudah digunakan (user friendly). Sehingga mahasiswa manapun mampu menggunakan dan memanfaatkan OPAC dan Repository tersebut. Ini terlihat Layanan User interface berjalan cukup baik dimana Interaksi antarmuka yang menghubungkan pengguna dengan koleksi digital perpustakaan yang tersimpan dan ditampilkan dalam bentuk wakil dokumen ( metadata) yang dapat diakses full text khususnya buku referensi seperti skripsi, thesis dan disertasi.

Staf perpustakaan selain memiliki skill di bidang dokumentasi dan teknologi informasi, ia juga wajib memiliki skill dalam berkomunikasi yang baik. Namun sikap dan prilaku staf perpustakaan pusat UIN Raden Intan pada umunya dirasakan pemustaka kurang ramah dan kurang empaty. Namun demikian Staf Perpustakaan memberikan layanan cukup cepat. Ini menunjukkan bahwa maskipun pustakawan bersikap kurang nyaman tetapi dalam hal pelayanan perpustakaan cukup efektif dan tidak memakan waktu yang lama.

Dilihat dari Fasilitas penunjang seperti toilet, mushulla, tempat pakir, pemustaka merasakan sudah cukup baik. Selain itu tata ruang, pencahayaan dan AC (air conditioner) cukup baik dan terjaga kenyamanan yang membuat sebagian besar mahasiswa betah di perpustakaan.

\section{B. Persepsi Pemustaka Terhadap Kebijakan Layanan \\ Persepsi Pemustaka terhadap kebijakan} Layanan perpustakaan dapat dilihat pada tabel dibawah ini:
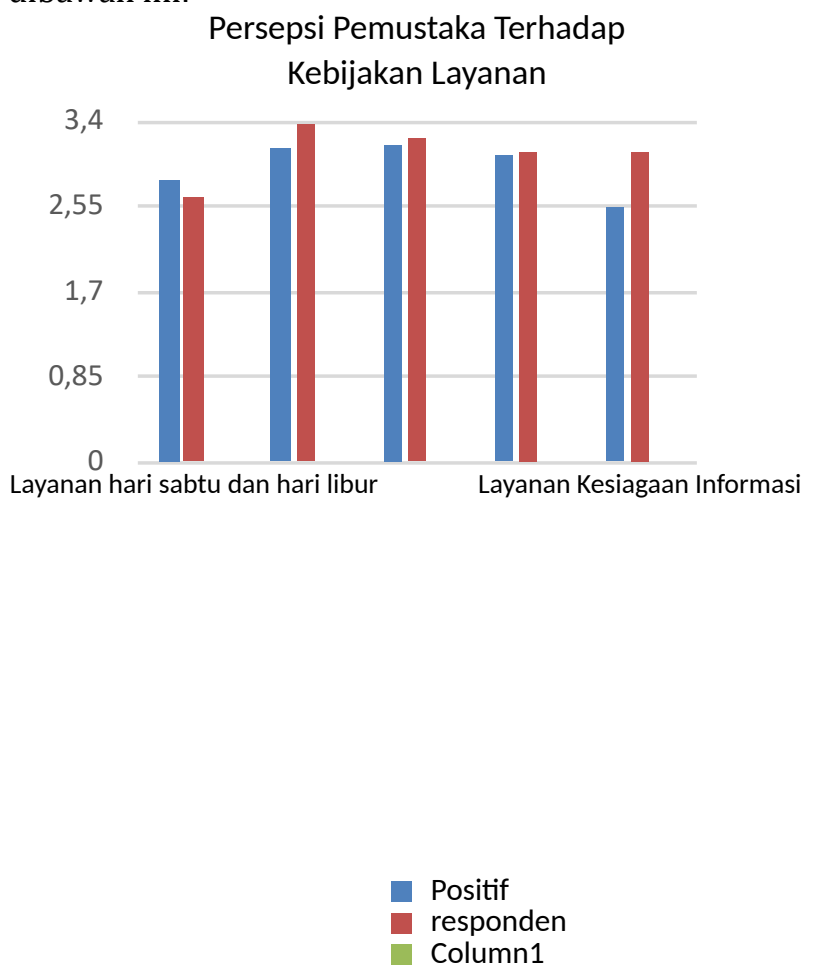

Persepsi pustakawan terhadap perkembangan manajemen perpustakaan UIN Raden Intan di Era digital pada tabel menunjukkan bahwa a) semakin adanya perkembangan di bidang teknologi informasi dan komunikasi maka manajemen layanan perpustakaan tentu saja ikut meningkat yang memberikan kenyamanan dan kelonggaran dalam memanfaatkan perpustakaan yaitu memungkinkan pemustaka dapat meminjam buku di hari libur seperti sabtu dan minggu (kecuali hari besar agama dan nasional); b) adanya layanan SMS (Short messsage service) yaitu pesan singkat yang digunakan untuk mengirimkan pesan secara digital ke pemustaka terutama mengenai informasi yang berkaitan dengan jasa layanan seperti masalah denda, peringatan kewajiban pemustaka untuk mengembalikan buku sehingga pemustaka tidak dibebani dengan denda yang berkepanjangan dan hutang yang wajib dibayarkan keperpustakaan, selain itu melalui SMS ini pemustaka berharap dapat memperpanjang pinjaman buku perpustakaan tanpa harus si pemustaka wajib hadir di perpustakaan cukup melalui layanan daring. Namun perpanjangan perpustakaan 
melalui SMS ini perlu dimemperhatikan masalah daftar tunggu peminjaman (ada atau tidaknya pemustaka lain memesan buku perpustakaan dengan judul yang sama) dan berapa kali dibolehkan pemustaka untuk memperpanjang, jika tidak dibatasi maka si peminjam dapat meminjam buku tersebut selamanya. Ini dapat merugikan orang lain yang mencari buku yang sama harus mengalami daftar tunggu yang sangat lama; c) Layanan pengiriman dokumen berbasis android, terutama koleksi perpustakaan yang tidak dibuka secara keseluruhan (full taxt) sehingga pemustaka tidak dapat mendownload secara keseluruhan kecuali izin dari perpustakaan. Hal ini tentu saja pemustaka berharap agar mereka dapat memperoleh layanan ini yaitu layanan pengiriman dokumen berbasis android dimanapun, kapanpun dan siapapun dapat dengan cepat menerima pengiriman dokumen yang dimaksud.; d) Jasa pengiriman dokumen, jasa ini sangat diperlukan terutama pengguna perpustakaan yang memiliki jam sibuk di lembaga sehingga mereka sulit keluar dari ruangan kantor sedangkan mereka sangat membutuhkan dokumen tersebut dengan cepat, oleh karena itu dalam situasi ini mereka sangat membutuhkan jasa pengiriman dokumen secara cepat dan tepat; e) layanan kesiagaan informasi yaitu layanan informai berkaitan dengan koleksi terbaru yang selalu uptodate baik melalui brosur-brosur, papan pengumuman dan lain sebagainya; ataupun informasi melalui digital, berita berita pada layar website perpustakaan.

\section{Persepsi Pemustaka Terhadap Kebijakan Koleksi}

Persepsi Pemustaka Terhadap Kebijakan Koleksi

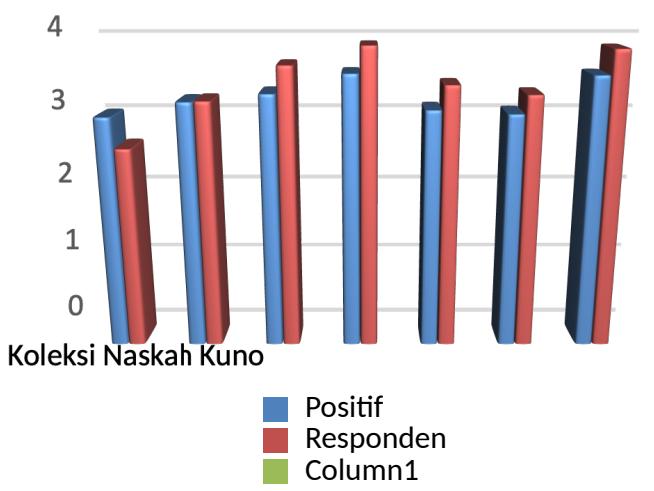

Persepsi pemustaka terhadap pengembangan koleksi, adalah bahwa perpustakaan UIN Raden Intan memiliki koleksi yang semakin beragam dalam subyek dan content (isi) baik itu content internasional, nasional maupun lokal; baik itu berbentuk buku maupun jurnal atau majalah, baik itu pemustka umum maupuun dipabel, antara lain : seperti koleksi Naskah kuno (musium) yaitu koleksi berupa perkembangan budaya pemikiran manusia dalam bentuk tulisan baik tercetak maupun digital; koleksi khusus dipabel; koleksi khusus UIN-ana (pemustaka sering merasakan kesulitan mencari informasi yang berkaitan UINana seperti pidato, orasi ilmiah, ceramah dan lain sebagainya; koleksi e-journal, koleksi CD-ROM dan E-Book; Koleksi Surat Kabar (internasional, provinsi dan lokal); dan koleksi film, Animasi sejenisnya.

Namun dalam pengembangan koleksi buku baik itu tecetak maupun berbentuk tetap memiliki konsep yang sama yaitu sekurangnya mencakup komponen sebagai berikut:

1. Purpose of the library

2. Community served and its needs

3. Scope and depth of the collection

4. Type of intormation needed to be acquired

5. Budget

6. Space

7. Established guidelinee

8. Policy governing use of materials

9. Hardware requirements

10. Charactersitic of verios media

11. Media preferences

12. Trends in information packaging (James Cabeceira, 1982:15)

\section{Persepsi Pemustaka Terhadap Kebijakan Fasilitas Umum}

Persepsi pemustaka terhadap kebijakan fasilitas umum dapat dilihat pada tabel dibawah ini: 


\section{Persepsi Pemustaka Terhadap Kebijakan Fasilitas Umum}

Persepsi pemustaka terhadap kebijakan fasilitas khusus dapat terlihat pada tabel dibawah ini:

4

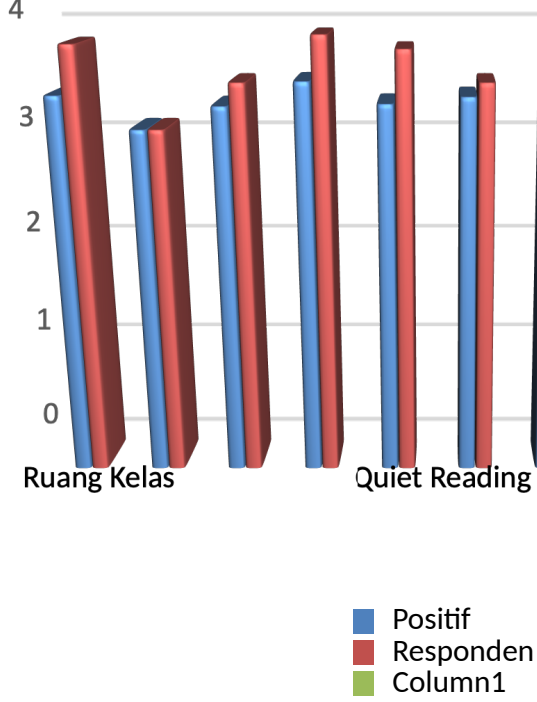

Perpustakaan era digital sebaiknya memiliki fasilitas ruangan yang cukup lengkap yaitu ruang kelas (untuk pendidikan pemakai, seperti orientasi perpustakaan, pelatihan pencarian informasi, pelatihan pengolahan referensi untuk karya tulis ilmiah dan sebagainya); perpustakaan harus juga memiliki ruang rapat tersendiri yang tidak mengganggu fasilitas umum lainnya jika akan rapat internal; ruang perpustakaan harus memiliki ruang pertemuan (misalnya pertemuan antar kepala perpustakaan untuk kegiatan MoU dan lain lain); Ruang Audotorium untuk kegiatan nonton bareng film-film yang berkaitan edukasi dan histori; ruang diskusi untuk pemustaka (mahasiswa UIN); Ruang quiet Reading Room yaitu ruang yang sunyi senyap yang diperuntukan mahasiswa untuk konsentrasi dalam menimbah ilmu; ruang baca biasa yaitu ruangan yang tidak membatasi mahasiswa dalam bersantai membaca tapi serius, dsini mahasiswa dapat membawa makanan minuman di dalam ruangan; ruangan penerbitan dan penjilidan buku; ruang komputer karena tidak semua mahasiswa selalu membawa laptop sehingga perpustakaan perlu juga menyediakan ruangan komputer untuk mencari informasi dan mengambilnya; Laboratorium komputer (khusus untuk pelatihan dan pendidikan serta penelitian).

\section{E. Persepsi Pemustaka Terhadap Kebijakan Fasilitas Khusus}

\section{Persepsi Pemustaka Terhadap Kebijakan} Fasilitas Khusus

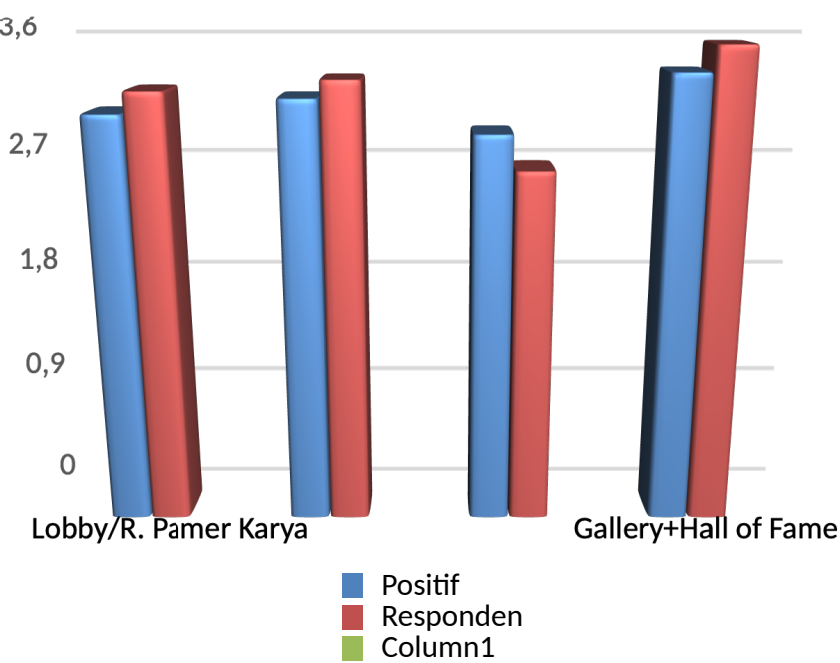

Perpustakan UIN Raden Intan di Era Covid 19 menunju New Normal Lifestyle sebaiknya memiliki 1) Lobby/Ruang Pamer Karya yaitu diperuntukan memanjang hasil karya sivitas akademika yang cemerlang dan diakui secara lokal, nasional dan internasional yang memiliki nilai seni atau karya sastra yang unik, menarik dan indah sehingga dapat dilihat oleh seluruh civitas akademika dan masyarakat umum; 2) ruang Stage/panggung terbuka, mahasiswa UIN Raden Intan sangat aktif dan kreatif banyak kegiatan mereka lakukan disekitar UIN, oleh karena itu semua kegiatan yang bersifat orasi, pidato, ceramah dapat dilakukan diruang ini.; 3) Cineplex, banyak mahasiswa membuat video yang baik dan bagus namun mereka tidak memiliki fasilitas untuk promosi agar diakui dan dinilai karya mereka, oleh karena itu perpustakaan perlu menyediakan ruangan cineplex untuk mengembangkan nilai seni dan kreativis mereka dalam membuat film pendek mereka.; 4) Gallery + Hall of Fame, perpustakaan UIN Raden Intan Sebaiknya memiliki ruangan seminar yang cukup besar yang dapat memuat 300 peserta untuk kegiatan seminar, lokakarya dan gallery bagi penerbit untuk promosi buku terbaru mereka. 


\section{F. Hasil Penelitian Mengenai Harapan Pemustaka Layanan Perpustakaan}

- layanan informasi yang lebih beragam baik dalam subjeknya maupun dalam media pengemasan (digital, elektronik, video, CD-ROM, piringan hitam), dan mudah diakses

- Informasi Literatur bisa diperoleh dengan cepat dan relevan seperti bibliografi khusus

- Adanya jasa terjemahan khususnya buku-buku yang berbahasa asing

- Adanya jasa percetakan dan penerbitan buku

- mesin bookdrop di setiap fakultas

- adanya jasa pengiriman dokumen

\section{Koleksi perpustakaan}

- Koleksi tercetak terbitan internasional lebih banyak baik itu berbentuk buku maupun berbentuk elektronik

- Melanggan online jurnal internasional

- Subyek dan jenis koleksi lebih lengkap terutama koleksi referensi seperti UINana, Lampung-ana, koleksi khusus untuk dipabel

- Jumlah buku yang dipinjamkan diperbanyak yaitu maksimal 5 buku dengan jangka pinjam koleksi selama 2 minggu serta dapat diperpanjang kembali.

- Pemustaka lebih dilibatkan dalam pengadaan koleksi agar buku yang tersedia di perpustakaan sesuai dengan kebutuhan pemustaka dan kurikulum pembelajaran.

\section{Fasilitas perpustakaan}

- Fasilitas yang diberikan lebih mudah dan user-friendly

- OPAC Perpustakaan terintegrasi antara pusat dan fakultas

- Lingkungan Belajar yang nyaman

\section{SDM (Staf Perpustakaan)}

- Staf perpustakaan selalu menginformasikan penambahan koleksi terbaru dan meningkatkan jasa perpustakaan kepada pengguna

- $\quad$ Staf perpustakaan yang ramah, proaktif dan terbuka

\section{SIMPULAN}

Dari uraian diatas dapat disimpulkan bahwa begitu besar harapan dan persepsi mereka terhadap perkembangan perpustakaan UIN Raden Intan di Era Covid 19 Menunju New Normal Lifestyle. Yaitu mereka menginginkan pembangunan dan pengembangan perpustakaan UIN Raden Intan ada penggabungan 4 (empat) konsep library yaituGreen library, Academic Library, Supermarket Library, dan hummy library

1) konsep Green Library yaitu perpustakaan yang sejuk, baik lingkungan maupun penghuninya, ramah tamah, tegur sapa, bersih (adanya sedianya air bersih dan hand sanitilizer), hijau, indah dan keamanan yang terjamin bagi pengguna perpustakaan.

2) konsep Academic Library yaitu perpustakaan menjadi pusat ilmu pengetahuan dan keterampilan pada sistem e-leraning, e-research dan Information Literacy. Perpustakan diharapkan menjadi pusat knowledge manajemen perguruan tinggi.

3) konsep Supermarket Library yaitu Layaknya supermarket, perpustakan menawarkan jasa dan produk sesuai kebutuhan manusia, banyak diskon, banyak melakukan promosi, memiliki pertunjukan pertunjukan seni maupun ilmiah sehingga menarik pelanggan untuk hadir di perpustakaan, mendatangkan orang-orang hebat yang memiliki karakter dan pengetahuan beragam seperti politikus, artis, motivator, dan juga menawarkan jasa pengiriman produk baik berbentuk buku elektronik maupun berbentuk buku, dan jasa penterjemah.

4) konsep Home Library yaitu perpustakaan layaknya sebuah rumah yang lengkap fasilitasnya: ada mushola, ada ruang istirahat, ada ruang belajar, ada lobby, ada beranda, ada ruang makan dan minum, ada ruang home theater, ada wifi dan sebagainya serta memiliki area parkir cukup luas dan aman sehingga pelanggan merasa betah dan nyaman layaknya dirumah sendiri.

Adapun saran pengembangan sistem manajemen perpustakaan UIN Raden Intan Lampung Di era covid 19 menuju new normal lifestyle sebagai berikut: 
- Perpustakaan UIN Raden Intan perlu melakukan kerjasama dengan perpustakaan lain di bidang peminjaman koleksi dan pengadaan koleksi bersama.

- Perpustakaan UIN Raden Intan perlu melakukan atau memiliki aplikasi layanan pengiriman dokumen dan pembayaran di tempat seperti gopay atau bank untuk transfer biaya pengiriman ataupun denda dari peminjaman.

- Perpustakaan menyediakan layanan dering perpustakaan baik melalui WA (whatsapp), telegram dan lain sebagainya untuk memudahkan komunikasi dengan pemustaka.

- $\quad$ Staf Perpustakaan UIN Raden Intan perlu meningkatkan keahlian dibidang teknologi komunikasi dan informasi

- Staf Perpustakaan lebih kreatif dalam melakukan pencarian ebook-ebook gratis agar selama perpustakaan Lockdown atau perpustakaan tutup layanan informasi masih tetap berjalan dengan baik melalui pengiriman ebook ebook gratis.

- Perpustakaan perlu melakukan Webinarwebinar di bidang perpustakaan seperti literasi informasi, bedah buku dan lain sebaginya

- Perpustakaan perlu adanya jasa layanan penterjemahan, percetakan buku monograp hasil penelitian, dan jasa referensi seperti pembuatan sitasi dan rujukan ilmiah.

\section{DAFTAR PUSTAKA}

Buku

Evans, G. Edward and Margaret R. Zarnosky (2002). Developing Library and Information Center Collections. Colorado : Libraries Unlimited.

Hartono. (2016). Manajemen Perpustkaan Profesional :Dasar-dasar Teori Perpustakaan dan Aplikasinya (hlm. 4). Jakarta :Sagung Seto.

Hartono, (2017). Pengetahuan Dasar Perpustakaan Digital : Konsep, dinamika, dan transformasi. (hlm. 30 ). Jakarta :Sagung Seto.

Lasa Hs. (2009). Kamus Kepustakawanan Indonesia. (hlm. 316). Yogyakarta :Pustaka Book Publisher, 2009
Kinicki, Angelo dan Robert, Kreitner. 2003. Organizational Behavior Key Concept, Skills and Best Practice. (hlm. 67). Boston: Mc. Graw Hill.

Pandit, Putu Laxman dkk. (2007). Perpustakaan digital : Perspektif perpustakaan Perguruan Tinggi Indonesia. (hlm. 29). Jakarta : Sagung Seto.

Rubin, Richard E. (2004). Foundations of Library and Information Science ${ }^{2 n d E d} ., N e w$ York : Neal-Schuman Publishers.

Schermerhorn, Hunt, dan Osborn. (2005). Organizational Behavior Ninth Edition. (hlm. 100). America: John Wiley \& Sons. Inc.

Sutarno NS. ( ( $\left.\begin{array}{llll}2 & 0 & 0 & 6\end{array}\right)$. Manajemen Perpustakaan :Suatu pendekatan praktik. (hlm. 100, 141). Jakarta :Sagung Seto.

Suwarno, Wiji. (2016). Library life style (Trend dan ide kepustakawan). (hlm. 20) Yogyakarta :LembagaLadang Kata, 2016

\section{Surat Kabar Online}

BBC.Com, PSBB jakarta mulai 10 april selama dua minggu, namun berapa lama perlu diterapkan. https://www.bbc.com/ indonesia/indonesia-52104441

Kompas.com, Diumumkan Awal Maret, Ahli : Virus Corona Masuk Indonesia dari Januari, Https://www.Kompas/sains/read/ 2020/05/11/130600623

Kompas.com, Jokowi Instruksikan Bekerja diRumah, ini artinya Work from Home,https://www.kompas.com/tren/ $\underline{\mathrm{read} / 2020 / 03 / 16 / 195035165}$

\section{E-Book}

Cathy De Rosa, dkk, (2005). Perceptions of Libraries and Information Resources : A Report to the OCLC Membership. Dublin, Ohio, USA : OCL Online Computer Library Center, Inc.

Kamus Besar Bahasa Indonesia (KBBI Dering) https://kbbi.kemdibud.go.id

---- UU No.43 Tahun 2007 tentang Perpustakaan.

Papy, Fabrice, (Ed.). (2008). Digital Library. (Hlm. 3). London : ISTE 